\title{
ZPE: AN ANALYSIS FOR THE SOCIO-ECONOMIC DEVELOPMENT OF THE WEST REGION OF MATO-GROSSO.
}

Rosinei Silva Ferreira ${ }^{a}$, Sayonara Nobre de Brito Lordeloa ${ }^{a}$ Aloísio Santos Nascimento Filho ${ }^{a}$.

${ }^{a}$ Programa de Pós-graduação - GETEC, SENAI CIMATEC

\begin{abstract}
The Brazil has twenty-four authorized ZPEs distributed in several cities, however only one in operation. This study aims to identify obstacles in ZPEs with a focus on the Mato-Grosso ZPE. It also assessed whether this business model is economically favorable and whether the type of professional training offered is adherent to employability in this segment. Based on a systematic review of the literature on the subject to profile of work force abilities were compared through studies professional technical courses available at western region of Mato-Grosso. Empirical results suggest that the ZPE model is economically favorable, but that it requires attention as to the type of professional training courses offered.
\end{abstract}

Keywords: Export Zone; Industrial profile; Qualification of labor.

\section{ZPE: UMA ANÁLISE PARA O DESENVOLVIMENTO SÓCIO ECONOMICO DA REGIÃO OESTE DE MATO-GROSSO.}

Resumo: O Brasil possui vinte e quatro ZPEs autorizadas distribuídas em várias cidades, porém apenas uma em operação. Este estudo visa identificar obstáculos em ZPEs com foco na ZPE de Mato-Grosso. Também avaliou se esse modelo de negócio é economicamente favorável e se a modalidade de formação profissional oferecida é compatível com a empregabilidade nesse segmento. Com base em uma revisão sistemática da literatura sobre o tema e o perfil de competências da força de Trabalho, foram realizadas comparações por meio de estudos dos cursos técnicos profissionais disponíveis na região oeste de Mato-Grosso. Os resultados empíricos sugerem que o modelo ZPE é economicamente favorável, mas que requer atenção quanto ao tipo de cursos profissionalizantes ofertados.

Palavras-chave: Zona de Exportação; Perfil industrial; Qualificação de mão de obra. 


\section{INTRODUCTION}

There are several concepts for Export Processing Zone - ZPEs, however for some international organizations such as United Nations Conference on Trade and Development - UNCTAD, United Nations Organization for Industrial Development UNIDO, International Organization Labor - ILO, the best definition is that they are industrial districts that are encouraged, and installed in a geographically delimited area. They were created through laws by the federal government focused on the development of companies that are apt for export, and thus, enjoy tax benefits in order to become more competitive in the international market. According to the Ministry of Industry, Foreign Trade and Services - MDIC, it is considered an important economic and social development program, as its objective is to contribute powerfully to attracting investments, generating jobs, correcting regional imbalances and promoting exports.

Currently, according to the MDIC, Brazil has twenty-four authorized export processing zones, which are distributed in twenty states of the national territory: Acre, Espírito Santo, Mato Grosso do Sul, Sergipe, Roraima, São Paulo, Rio Grande do North, Piauí, Ceará, Pernambuco, Minas Gerais, Tocantins, Pará, Mato-Grosso, Bahia, Santa Catarina, Rio de Janeiro, Paraíba, Rio Grande do Sul and Maranhão. Chart 1 outlines the location of authorized ZPEs in Brazil. However, according to the National Council for Export Processing Zones - CZPE, of the twenty-four zones approved in Brazil, only one is in operation, that of the State of Ceará. It would be appropriate to analyze, if of the proposed objectives of functioning of an ZPE, such as that of attracting investments, job creation, corrections of regional imbalance and export competitiveness, which are in fact ensured taking as a parameter that of all the ZPEs mentioned in the table below however, only one is in operation in Brazil, the one located in the State of Ceará. Considering the proposal for social and economic development that an ZPE can bring to the city where it is installed and positively influence all the surroundings of that city and state, the question is, if it is such an impactful project why the other ZPEs projected at the national level have not yet are working, considering that a good part of the projects have been validated since the year 1.994? What impacts would the operation bring to the State of MT in terms of employability, industrial competitiveness and social equivalence? The table below shows the authorized ZPEs in Brazil by region. 
Table 1. ZPEs in Brazil by Region, State and City.

\begin{tabular}{|c|c|c|}
\hline Region & State & City \\
\hline \multirow{4}{*}{ North } & Acre & Senador Guiomard \\
\hline & Roraima & Boa Vista \\
\hline & Tocantins & Araguaína \\
\hline & Para & Barcarena \\
\hline \multirow{6}{*}{ Southeast } & São Paulo & Fernandópolis \\
\hline & Rio de Janeiro & Itaguaí \\
\hline & \multirow{2}{*}{ Espírito Santo } & Vila Velha \\
\hline & & Aracruz \\
\hline & \multirow{2}{*}{ Minas Gerais } & Uberaba \\
\hline & & Teófilo Otoni \\
\hline \multirow{2}{*}{ South } & Rio Grande do Sul & Rio Grande \\
\hline & Santa Catarina & Imbituba \\
\hline \multirow{3}{*}{ Midwest } & Mato-Grosso & Cáceres \\
\hline & \multirow{2}{*}{ Mato-Grosso do Sul } & Corumbá \\
\hline & & Bataguassu \\
\hline \multirow{9}{*}{ Northeast } & Bahia & Ilhéus \\
\hline & Maranhão & São Luiz \\
\hline & Paraíba & João Pessoa \\
\hline & Piauí & Parnaíba \\
\hline & Sergipe & Barra dos Coqueiros \\
\hline & \multirow{2}{*}{ Rio Grande do Norte } & Assú \\
\hline & & Macaíba \\
\hline & Ceará & São Gonçalo de Amarante \\
\hline & Pernambuco & Jaboatão dos Guararapes \\
\hline
\end{tabular}

Source: Adapted from MDIC, BRASIL. (2012).

\subsection{ZPEs In Brazil.}

In a contextualization approach, ZPEs are not a nationally created project, the model has been in operation for many years in several countries around the world. Of these, there are both positive and negative records about the effectiveness of the ZPE functionality. Asia alone, according to Farole and Akince (2011), concentrates more than a quarter of all the ZPEs in the world. Many more are in the United States, the Caribbean and Central America. In Brazil, companies that wish to settle in an ZPE have several benefits and incentives relevant to their competitiveness, however, they have clear rules to comply with, among the benefits as recorded by the MDIC are in accordance with table below: 
Table 2 - Incentive for a company installed in the ZPE Brazil

\begin{tabular}{|c|c|}
\hline & INCENTIVES FOR ZPE BRASIL \\
\hline 1 & $\begin{array}{l}\text { Exchange and administrative tax incentives, granted by the federal government through } \\
\text { law } 11.508 / 2007 \text { with changes introduced by laws } 11.732 \text { / } 2008 \text { and } 12.767 / 2.012 \text {. }\end{array}$ \\
\hline 2 & $\begin{array}{l}\text { Suspension of taxes and contributions such as: import tax, IPI, PIS, COFINS, PIS - import } \\
\text { and COFINS - import and additional to the merchant marine renewal freight. Benefits in } \\
\text { the acquisition of inputs in the domestic market and in exports. }\end{array}$ \\
\hline 3 & $\begin{array}{l}\text { ZPE companies can allocate } 20 \% \text { of the gross revenue resulting from the sale of goods } \\
\text { and services to the domestic market, however, paying all taxes due. }\end{array}$ \\
\hline 4 & Reduction of up to $75 \%$ of the IR for a period of 10 years. \\
\hline 5 & $\begin{array}{l}\text { Foreign exchange freedom, that is, they can keep abroad up to } 100 \% \text { of the currencies } \\
\text { obtained in their exports. }\end{array}$ \\
\hline 6 & $\begin{array}{l}\text { For import and export, licenses and authorizations from federal agencies are released, } \\
\text { except those for health control or environmental protection. }\end{array}$ \\
\hline 7 & $\begin{array}{l}\text { Tax, exchange and administrative benefits are guaranteed for } 20 \text { years and may be } \\
\text { extended. }\end{array}$ \\
\hline 8 & $\begin{array}{l}\text { They can enjoy state benefits such as exemption from ICMS on imports and purchases } \\
\text { on the foreign market. }\end{array}$ \\
\hline
\end{tabular}

Source: Adapted from MDIC, BRASIL. (2012).

The ZPEs are instruments installed in various parts of the world and aim to promote the following objectives simultaneously:

1. Attract foreign investments aimed at export.

2. Put national companies on a competitive footing with their foreign competitors.

3. Create jobs.

4. Increase in added value of exports.

5. Disseminate new technologies.

6. Implement more modern management practices.

7. Correct regional imbalances.

The Brazilian Export Processing Zones were created and authorized after the Federal Constitution of 1988.

The Ceará ZPE started its operations in April 2013, has a total area of $4,271.41$ hectares. According to the federal government of Ceará, in the first six years of operation, the ZPE installed there moved more than 12 million tons in products. According to the administrator of ZPE Ceará, (2020), it has four large industries installed in operation. Also according to data from the administrator of the ZPE of Ceará, in 2019 it had its best result in sales since the beginning of its activities, totaling $\mathrm{R} \$ 48.93$ million, an increase of $6.17 \%$ in relation to 2018 , year that had already been the company's record.

\subsection{ZPE Mato-Grosso-Brazil.}

The State of Mato-Grosso is known as the granary of Brazil, due to its aggressive performance in the production of grains such as soybeans, corn and cotton, it is still one of the largest cattle producers in the country. According to the government website of the state of Mato-Grosso, the State has acted in the development of important economic areas, such as: agribusiness, tourism, fish farming and jewelry 
production. Highlight for agribusiness considering the already mentioned power of the State in the production of grains and livestock. According to the state government website, the state's GDP went from R \$ 12.3 billion in the year of 1999 to R \$ 80.8 billion in the year of 2012, adding a growth of $554 \%$ compared to the national GDP that in this year period amounted to $312 \%$ according to data (GOVERNO DE MT, 2015).

According to Euvaldo Lodi Institute - IEL MT, the State of Mato-Grosso currently has 10,390 active industries, $81 \%$ of which are micro companies, $15 \%$ small, $4 \%$ medium and $1 \%$ large. It is observed that there is a well-defined performance by sizes of industries in the State, being a predominant characteristic for micro industry that makes up $81 \%$ of the State's industrial park, and that need incentives to leverage their competitiveness. The ZPE Proposal for the city of Cáceres follows with expectations of expanding and strengthening the industrial segment of the State.

Cáceres is located in the western region of Mato-Grosso and comprises 20 municipalities. It is a reference city, considered a hub for health, education, among other points. The city is a century old, founded in the year of 1,778 , according to IBG 94,376 inhabitants. It is on a dry border with Bolivia, whose nearest city is $102 \mathrm{~km}$ from Cáceres, its main economic activity is livestock, considered by the State of MatoGrosso to be one of the largest cattle herds in Brazil.

The ZPE proposal for the city of Cáceres is one of the main bets for advancing the economy of the region and the State. The donated area for the installation of the 247 hectares ZPE is located in the industrial district of Cáceres. With an expectation of generating more than 10,500 direct and indirect jobs. The choice of the city of Cáceres to implement the ZPE was due to the river structure that makes intermodal transportation possible, as it makes important connections both to Bolivia and to the Pacific Ocean, giving access to Chile. The Paraguay-Paraná waterway as it is known is an alternative modal to state exports. The Cáceres ZPE was authorized in the year 1999, through the publication of Decree-Law No. 99,043, of March 6, 1990. As can be seen in image 1, below, the works are still far behind for operation, emphasizing that the Cáceres ZPE was authorized in the year 1999, that is, 30 years ago and, to date,

the facilities necessary for operation have not yet been completed.

The city of Cáceres is considered the educational hub of the Western region, as it encompasses several educational institutions, including the very headquarters of State University of Mato-Grosso- UNEMAT, one of which is National Industrial Learning Service - SENAI. The curriculum profile adopted by the professional technical training institutions adhering to the industrial work that would be the focus of the ZPE was evaluated. In this case, we would have SENAI as the provider of professional courses adhering to the industry. In 2019, the SENAI unit in Cáceres received an investment of more than R \$ 4 million in infrastructure, machinery and equipment, and according to the SENAI MT project sector, one of the objectives of this investment was to expand the capillarity of professional training to serve the city and the surrounding region. The investments included the installation of new laboratories aimed at the electrical, industrial maintenance, automation and food segments. Thus, according to SENAI, the unit would be prepared to meet a possible demand for training of labor for the SPA. The unit currently offers technical courses in occupational safety, electrotechnics and logistics. However, SENAI itself for acting upon industrial demand positions itself as one of those interested in meeting the possible demands of industries installed within the ZPE by making the necessary adjustments to its portfolio of technical courses so that they prioritize the hiring of local labor. 


\section{METHODOLOGY}

The operation model of an ZPE causes the construction of a more specific portfolio for the training of labor through SENAI, which is a reference in the training of workers for industry and that such training promotes the development of the necessary skills so that knowledge gaps reduced and that, in turn, enables conditions of priority employability for residents around the ZPE and, consequently, a high export of labor from other States is not necessary, which even hurts one of the macro objectives of the project of the ZPE of Brazil. In order to reach this parameter of necessity, a comparison was made of the types of courses currently offered by SENAI based on the most technological industrial profile used by the ZPEs, although it is not yet fully understood which industrial branches will be installed in the Cáceres ZPE, but by the profile curriculum of the courses, they were at the time formatted to attend the existing industrial production chain based on technologies currently practiced for that industrial pole.

In addition, the qualitative method was applied through the research of industrial maturity carried out by SENAI MT in 2019 by sampling in industries of the State in order to identify the profile of industries in Mato-Grosso regarding the current level of technological maturity confronting the characteristics that permeate industry 4.0, as shown in the figure below the survey consolidated:

Figure 1 - Result of the research regarding the technological profile of MT industries

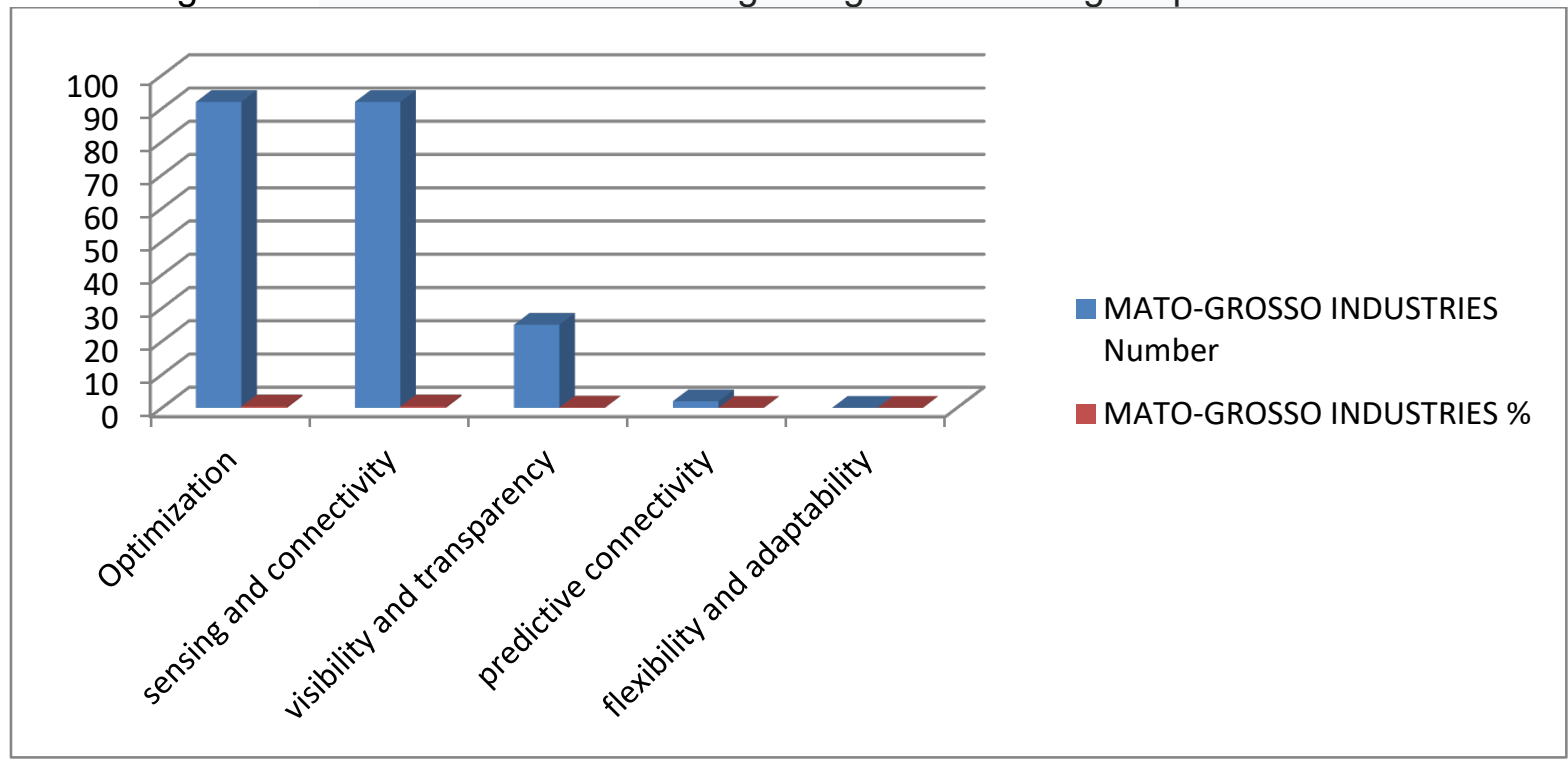

Source: Research of technological maturity of the State of MT. SENAI MT (2019)

It is identified in the result above that the technological level the State of MT partially meets the criteria of industrial and technological evolution based on industry 4.0 and that there are factors yet to be pursued. Thus, based on the parameters, the State has not yet experienced the process of modern and operating technology. In addition, a bibliographic search of texts and federal and international documents dealing with the ZPE in Brazil and in the world was used.

\section{RESULTS AND DISCUSSION}

Based on the research, it is noteworthy to highlight the benefits for companies that install themselves within an Export Processing Zone, as well as the proposal to 
generate greater social equality in the cities where they will be installed, considering that the project has the priority of installing in poor regions of Brazil. For discussion, some questions arise, such as: Is the proposed model for ZPE in Brazil today feasible or not? In a context of enhancing the industrialization process, it is possible to say that yes, it is a viable project because with the installation of new industries comes several other advantages, one of which is the generation of employment.

Another point, being a project that aims at economic competitiveness and social improvements, why is only one of the twenty four authorized, in operation? For this question it requires a deepening of the research considering that it is not only economic but also political factors. But the research noted that for Brazil, for MatoGrosso, the ZPE project would be a competitive differential both for the country considering the expansion in the export process and for the workers and secondary industries that feed back into the productive process of this great chain of operation.

\section{CONCLUSION}

This research aimed to analyze the Cáceres ZPE feasibility in terms of economic and social once that implementation may represents an opportunity for an underdeveloped region in the state of Mato-Grosso in Brazil.

However, it is not guaranteed if this employability will occur for the citizens of this region since the professional profile is still uncertain, considering that there is not vet a list of industries that would settle in this ZPE.

Furthermore, regarding the industrial profile of the Cáceres region and according to the survey, a primary profile of technologies that are still timid and that would not encompass competitive conditions in a large-scale export scenario that is the purpose of the ZPE is pointed out.

Thus, that the Cáceres ZPE will generate employment outside the state in the expectation of importing more skilled labor and of high added value and consequently frustrating the expectations of the region's residents. In addition to frustrating one of the main objectives of the project, which would be to increase income and employable for the local community.

\section{Acknowledgments}

I am grateful to SENAI MT as Regional Director Lélia Brun, for sponsoring the Master's studies at SENAI CIMATEC

\section{REFERENCES}

${ }^{1}$ BRASIL, Ministério do desenvolvimento indústria e comércio exterior. Conselho nacional das zonas de processamento de exportação - secretaria executiva. Brasília, 2012.

${ }^{2}$ FAROLE e AKINCE.. Special economic zones: Progress, emerging challenges, and future directions, World Bank, Washington, DC, 2011.

3 ZPE, Do Ceará. ZPECEARA, Ceará, 2020. Available at: <http://www.zpceara.gov.br/empresasinstaladas>. Accessed on: 29 Jun. 2020. 
4 MATO-GROSSO. Governo do Estado. 2015. Available at: <http://www.mt.gov.br/economia>. Accessed on: 10 Jun. 2020.

5 IEL MT, INTITUTO ELVALDO LODI. 2019. Available at: $<$ http://www.ielmt.ind.b/paraempresa/estudo-e-pesquisa>. Accessed on: 20 Jun. 2020.

6 SENAI MT, SERVIÇO NACIONAL DE APRENDIZAGEM INDUSTRIAL. 2019. Available at: <http://www.senaimt.ind.b/pravoce/cursos>. Accessed on: 10 Out. 2019. 